\title{
THE EFFECT OF KARS STANDARD SYSTEM ON EMPLOYEE COMPETENCE AND ITS IMPACT ON PERFORMANCE : STUDY IN RSUZA
}

\author{
Sandro Syahputra, Nasir and Faisal \\ Department of Management, Universitas Syiah Kuala, 23111, Indonesia \\ http://doi.org/10.35409/IJBMER.2020.3150
}

\begin{abstract}
This study aims to determine the direct and indirect effect of a hospital quality standard system of the Indonesian Commission for Hospital Accreditation (KARS) on the performance of dr. Zainoel Abidin Regional Public Hospital (RSUZA) through the mediating role of employee competence. The population of this study is 1,161 employees. The number of research sample is 298 employees. Sampling in this study is conducted with a minimum sample formulation using the Slovinformula. Data is collected by distributing closed question sheets (questionnaires) to all employees. The data is analyzed using SEM (Structural Equation Modeling) analysis techniques with the help of the AMOS 22 program. The result shows that KARS standard system has a significant effect on employee competence, KARS standard systemhas a significant effect on the performance, employee competence has a significant effect on performance, and employee competence has a mediation role in increasing the effect of KARS standard systemon the performance of RSUZA. These results contribute to the update the causality theories especially in management field, and also can be a reference for the practical persons especially the managers in RSUZA in developing their strategy. The limitation resides in the amount of variables that are only three, and also with the one object only. The originality lies in the model that combines several models from the previous ones, and uses SEM as the analysis method.
\end{abstract}

Keyword: KARS standard system, employee competence, performance.

\section{INTRODUCTION}

The new hospital management paradigm in Indonesia that goes hand in hand with public bureaucratic reforms has a conservative impact on hospitals to always prioritize on satisfactory service quality while continuing to achieve accountability in financial performance efficiently. This condition has been taking place in all hospitals in Indonesia, including the dr.ZainoelAbidinRegional Public Hospital (RSUZA) that is located in Banda Aceh city.

RSUZA is one of the Regional Public Service Agencies (BLUD) in Indonesia. While increasing regional development, this regional government hospital continues to grow dynamically as a leading health care center in Aceh Province. These development has made the RSUZA as the A class of A Government hospital in Indonesia thathas been accredited A. Even so, complaints from the public about health services at this hospital are still heard. The increase 


\section{International Journal of Business Management and Economic Review}

Vol. 3, No. 01; 2020

ISSN: 2581-4664

in the number of patients, which is not matched by the number of medical service facilities and the lack of ability of employees to optimally serve all the needs of patients, makes the performance of RSUZA still has some problems that need to be resolved with quality management. With these demands, for the last few decades, RSUZAhasbegun to adopt the concept of total service quality that is oriented in 2012 version of KARS, that is applied by now.

The Indonesian Commission for Hospital Accreditation (KARS), in the concept of service quality of RSUZAhas been going on since 1995 in various forms, such as Total Quality Control (TQC) and ServQual. However, the concept is still imperfect and continues to be refined in standard measurement criteria more thoroughly in order to obtain higher quality hospital accreditation standards and move towards international standards manifested in KARS 2012.

The implementation of KARS has made RSUZA a more qualified hospital marked by changes in the quality standards of management and public services. KARS has made hospitals able to improve service quality and better information communication management. Although KARS has not optimally improved the management of risk assessments better and has not sufficiently improved the quality of occupational health and safety control, the implementation of KARS in RSUZA has been able to make changes to employee competencies.

The KARS standard system at RSUZA has made employees must work with the new procedures. This condition makes employees should change the conventional way of working that has been done for years. Although the new procedure is full of difficulties, targets, and rules that make it difficult for employees to do so, the creation of standard procedures for all work activities will have an impact on the ability and expertise of employees. So that the implementation of KARS has improved the competency of employees and has an indirect impaci on hospital performance.

\section{LITERATURE REVIEW}

\section{The Effect of Standard System On Performance}

The application of ISO can change the orientation of an organizational culture towards a quality culture and ultimately can improve performance (Hardjosoedarmo, 2004). The Accreditation of quality assurance standards are a forum for communication and consultation between hospitals and accreditation board that will provide suggestions for improvements or recommendations for improving the quality of hospital services through the achievement of specified standards. Then, with the self-evaluation method, the hospital can find out which services are below the standard or need to be improved. This method can increase hospital awareness of the importance of efforts to improve quality. By knowing comparisons based on accreditation standards, hospitals can use them for the sake of budget submission and hospital planning/ development (Triwibowo, 2012). The standard principle according to ISqua in accreditation is one crucial thing that can favor performance According to (Crosby, 1984) in (Triwibowo, 2012). Application of quality standards will improve organizational performance (Kaziliūnas \& Vyšniauskienè, 2014).

\section{The Effect of Standard System On Competence}

Work standards that refer to ISO procedures can be carried out well by employees who have adequate competence, and at the same time, it is allegedly able to make employee competencies more adequate if they can carry out all existing procedures (Utami \& Basista, 


\section{International Journal of Business Management and Economic Review}

Vol. 3, No. 01; 2020

ISSN: 2581-4664

2011). Accreditation quality assurance standards can improve employee self-assessment. This condition will increase awareness of the employees of the importance of meeting standards and improving quality through various forms of training so that they can motivate employees to work well (Triwibowo, 2012). KARS can improve employee competence through work engagement and communication, multidisciplinary behavior, positive changes in organizational culture, and awareness (Ng, Leung, Johnston, \& Cowling, 2013).

\section{The Effect of Competence on Performance}

The competence of leaders and all employees is required to make it easier for an organization to achieve its objectives (Torang, 2013). Competence is always associated with the ability of employees and is one of the factors that determine the achievement of performance (Pasolong, 2008). Employee competence plays an important role both for individual and organizational performance (Zaim, Yaşar, \& Ünal, 2013).

\section{The influence of Standard Systemon organizational performance through employee competence.}

Implementing total quality management in an organization means making a substantial change in management (Hardjosoedarmo, 2004). If in achieving the target organization of human resources does not match the needs of consumers, then there may be a failure in terms of human resources, equipment, machinery, materials or organizational systems. For this reason, with total quality management, all organizational resources will be evaluated and improved. With quality standards all employees will be provided training and education so that organizational failure will be overcome (Hardjosoedarmo, 2004). Thus, KARS will play a role in organizational performance by improving employee competency.

\section{Research Paradigm and Hypothesis}

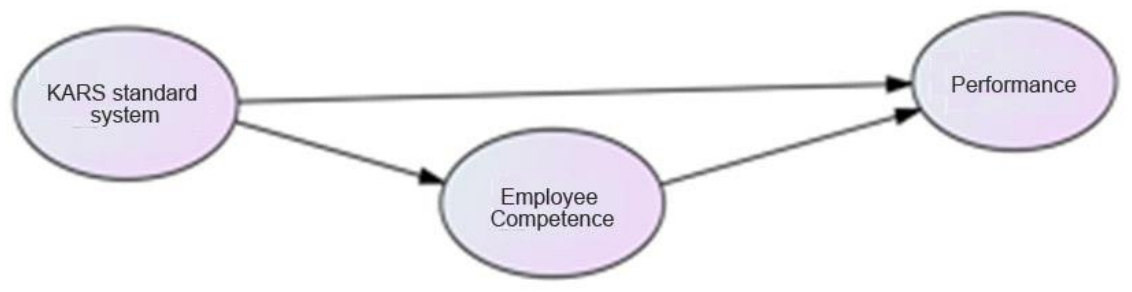

Figure 1. Research Paradigm

H1 = KARS standard system has a significant effect on employee competence

$\mathrm{H} 2=$ KARS standard system has a significant effect on the performance

$\mathrm{H} 3$ = employee competence has a significant effect on performance

H4 = employee competence has a mediation role in increasing the effect of KARS standard system on the performance

\section{METHOD}




\section{International Journal of Business Management and Economic Review}

Vol. 3, No. 01; 2020

ISSN: 2581-4664

The population in this study is 1,161 employees who worked atRSUZA. The number of samples is 298 employees. Sampling in this study is determined with a minimum sample formulation using the Slovin formula. Data is collected using the questionnaire. The questionnaire is a list of questions compiled systematically, then sent to be filled in by respondents, namely hospital employees.

This research is a causality verification study using Structural Equation Modeling (SEM) analysis tool that is operated through the AMOS 22 program. This study uses one exogenous variable, namely KARS Standard System (X) and one endogenous variable, namely the performance of RSUZA (Y). KARS standard system in this study means the KARS of 2012 version that is still applied until now. The influence of these two variables is strengthened by the mediating variable that is the employee competence $(\mathrm{Z})$. The constructs that is build in variables are : 1) KARS Standard System: Satisfaction, Contribution, Strategies, Service, and Capabilities (Cahyawati, Pratikto, \& Soenoko, 2013); 2) Employee competence : motives, traits (personal character), self-concept, knowledge, and skills (Wibowo, 2016). Performance RSUZA: procurement of medical equipment and medicines for patient needs, activity reporting, risk management, resource used management, patient and family satisfaction, staff satisfaction, patient demographics and clinical diagnosis, financial management, prevention and patient safety control, and family of patients and staff satisfaction (Kars, 2011).

\section{RESULT}

\section{Measurement Model}

Measurement Test Model is a confirmatory factor analysis (CFA)measurement model. This model explains whether the manifest variable (indicator) is strong enough to support the existence of the construct variables used in the model structure analysis. The contribution of manifest variable (indicator) is quite strong if the CFA value obtained>0.50. Confirmatory factor analysis of exogenous and endogenous constructs can be seen in Figure 2.

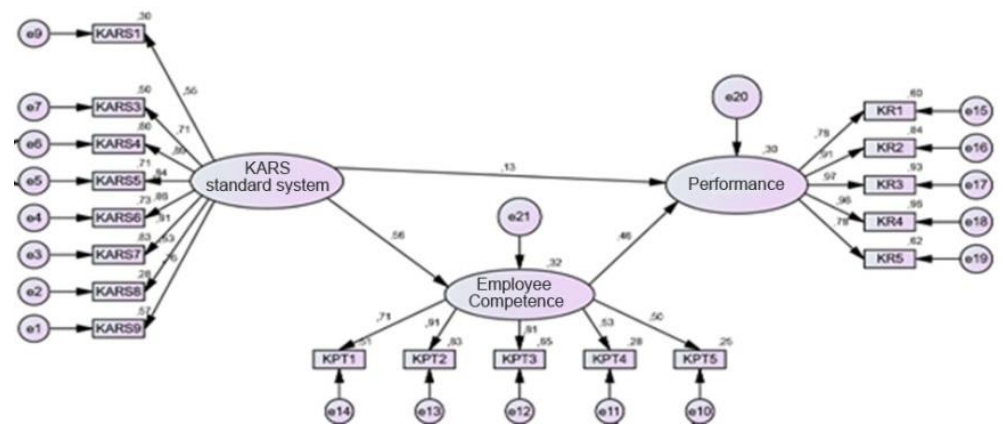

Figure 2. Confirmatory Factor Analysis Result 
International Journal of Business Management and Economic Review

Vol. 3, No. 01; 2020

ISSN: 2581-4664

Table 1.Loading Factor Research Variables

\begin{tabular}{|lll|l|}
\hline KARS9 & $<---$ & KARS & .757 \\
KARS8 & $<---$ & KARS & .533 \\
KARS7 & $<---$ & KARS & .909 \\
KARS6 & $<---$ & KARS & .855 \\
KARS5 & $<---$ & KARS & .840 \\
KARS4 & $<---$ & KARS & .894 \\
KARS3 & $<---$ & KARS & .709 \\
KARS1 & $<---$ & KARS & .547 \\
KPT5 & $<---$ & Competence & .504 \\
KPT4 & $<---$ & Competence & .530 \\
KPT3 & $<---$ & Competence & .806 \\
KPT2 & $<---$ & Competence & .912 \\
KPT1 & $<---$ & Competence & .712 \\
KR1 & $<---$ & Performance & .776 \\
KR2 & $<---$ & Performance & .915 \\
KR3 & $<---$ & Performance & .966 \\
KR4 & $<---$ & Performance & .981 \\
KR5 & $<---$ & Performance & .784 \\
\hline
\end{tabular}

The results of the confirmatory analysis calculationis explained as follows:

1. Confirmatory analysis of the variable of the implementation of KARS Standard Systemshows that from 9 (nine) indicators used, only 8 (eight) which have the loading value above 0.5 with a significance value of a regression weight below 0.05 . So, there is one indicator of this variable that must be discarded, namely KARS2 with a factor loading value of 0.30 or $<0.50$.

2. While the confirmatory analysis of employee competence variable and hospital performance variable from the 5 (five) indicators used in each variable, all have loading values above 0.5 with a significance value of a regression weight below 0.05 . So, there is no single indicator of employee competency variable and hospital performance variable that must be discarded.

Thus, it can be said that the indicator is representative enough to explain the unobserved variable and must be included in the processing of data afterward because the value is above 0.5 .

\section{Structural Equation Modeling Analysis}

This research uses an effective mediation analysis model. The analysis is conducted with the Full Model of Structural Equation Model (SEM)with the help of the AMOS 22 Application. The output of SEM analysis can be seen in Figure 3. 
Vol. 3, No. 01; 2020

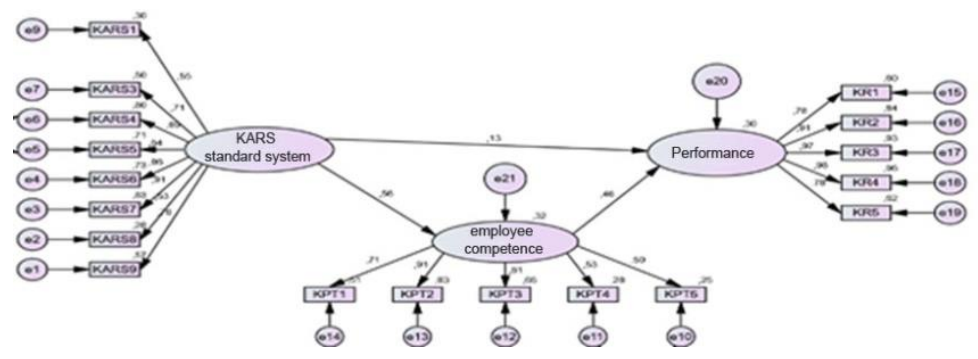

Figure 3. SEM Result

\section{a. The Evaluation of Goodness of Fit Criteria}

Structural Equation Model (SEM) analysis requires the Goodness of Fit criteria to obtain accurate decision making. The results of evaluating the Goodness of Fit criteria can be seen in Table 2.

Table 2. The goodness of Fit Measurement Model Criteria

\begin{tabular}{|c|c|c|c|}
\hline Size Index Criteria & Cut-off Value & Analysis Results & $\begin{array}{l}\text { Model } \\
\text { Evaluation }\end{array}$ \\
\hline Chi-square & $\begin{array}{l}\text { Approaching zero with the P- } \\
\text { value (probability) does not } \\
\text { exceed } 0.05 \text {. }\end{array}$ & $\begin{array}{l}153.378 \\
P=0.079\end{array}$ & Good \\
\hline CMIN & $\begin{array}{l}\text { Default Model Between } \\
\text { Saturated \& Independence } \\
\text { Model }\end{array}$ & $\begin{array}{l}\text { CMIN/DF=1179.831 } \\
\text { CMIN=153.378 } \\
\text { anging between } \\
\text { p-4942.425 }\end{array}$ & Good \\
\hline GFI, AGFI & Close to 1 & $\begin{array}{l}\mathrm{GFI}=0.919 \\
\mathrm{AGFI}=0.878\end{array}$ & Good \\
\hline $\begin{array}{l}\text { Baseline } \\
\text { Comparisons }\end{array}$ & Close to 1 & $\begin{array}{l}\text { NFI }=0.956 \\
\text { RFI }=0.940 \\
I F I=0.978 \\
T L I=0.970 \\
\text { CFI }=0.978\end{array}$ & Relatively Good \\
\hline $\begin{array}{l}\text { Parsimony } \\
\text { Adjusted Measures }\end{array}$ & $\begin{array}{l}\text { Ranging between } \\
\text { range value } 0-1\end{array}$ & $\begin{array}{l}\mathrm{P} \quad \text { ratio }=0.739 \\
\mathrm{PNFI}=0.706 \\
\mathrm{PCFI}=0.722\end{array}$ & Good \\
\hline RMSEA & $0.05-0.8$ & 0.058 & Good \\
\hline AIC & Between & 334.020 & Good \\
\hline
\end{tabular}




\section{International Journal of Business Management and Economic Review}

Vol. 3, No. 01; 2020

ISSN: 2581-4664

\begin{tabular}{|l|ll|l|l|}
\hline \hline & $\begin{array}{l}\text { Saturated \& Independence } \\
\text { Model }\end{array}$ & $\begin{array}{l}\text { between } \\
4798.425\end{array}$ & \\
\hline \multirow{2}{*}{ ECVI } & $\begin{array}{l}\text { Default } \\
\text { Saturated \& } \\
\text { Model }\end{array}$ & Independence & 1.219 & \\
& between 1.248-18.169 & Good \\
\hline
\end{tabular}

The goodness of Fit criteria is relatively good, with the Chi-square value being at the limit of the probability value of 0.079 . Then the CMIN value is greater than 2.The GFI, AGFI, and PCFI assessments are all close to 1 so that the model is said to be fit. Then the evaluation of NFI, RFI, IFI, TLI, CFI, all of them have their respective numbers above 0.8 or close to 1 so that the model can also be said to be fit.Then in the Root Mean Square Error of Approximation (RMSEA) values are obtained between $0.05-0.08$ so that the model is considered fit.

b. Analysis of Influence between Variables

Table 3.Estimate Regression Weight Influence Between Variables

\begin{tabular}{|c|c|c|c|c|c|}
\hline & & $\begin{array}{l}\text { Estimat } \\
\text { e }\end{array}$ & S.E. & C.R. & $\mathrm{P}$ \\
\hline Employee competence & $<--$ KARS & 0.514 & 0.056 & 9.230 & 0.00 \\
\hline Hospital performance & \begin{tabular}{l|l}
$<--$ & Employee \\
competence
\end{tabular} & 0.519 & 0.078 & 5.672 & .00 \\
\hline Hospital performance & $<--$ KARS & 0.131 & 0.066 & 2.002 & p.045 \\
\hline
\end{tabular}

Table 4.Standardized Regression Weights

\begin{tabular}{|l|l|l|l|}
\hline & & & Estimate \\
\hline Competence & $<---$ & KARS & 0.562 \\
\hline Hospital performance & $<---$ & Competence & 0.463 \\
\hline Hospital performance & $<---$ & KARS & 0.128 \\
\hline
\end{tabular}

\section{H1 (Accepted) :The Influence ofKARS Standard Systemon Employee Competence}

The application of a hospital quality standard system based on the 2012 version of KARS has a positive and significant effect on the employee competence at RSUZA with an influence value of 0.562 , meaning that if the implementation of KARS standard system increases by 1 unit, then employee competence will also increase by 0.562 units. The Influence of the Implementation of the KARSstandard systemon employee Competence at RSUZA is significant, with a significant probability value of 0.00 or less than 0.05 . This value is equivalent to the calculated C.R value of 9.230 , or greater than 1.96 so that the $\mathrm{Ha}_{2}$ hypothesis can be accepted, and $\mathrm{Ho} 2$ is rejected.

This condition is caused by KARS being able to increase work engagement and internal communication, increase multidisciplinary behavior and change the organizational culture towards a positive and full of awareness and responsibility so that employee competence will increase (Ng et al., 2013). The implementation of the Hospital Quality Standard System based on the 2012 version of KARS also creates quality operational procedures such as procedures on the 


\section{International Journal of Business Management and Economic Review}

Vol. 3, No. 01; 2020

ISSN: 2581-4664

quality of education and employee development through the Training program so that compliance with these procedures will improve employee competency (Utami \& Basista, 2011).

\section{H2 (Accepted) :The Influence of KARS Standard Systemon the performance}

The implementation of KARS standard system has a positive and significant effect on employee competence at RSUZA with an influence value of 0.128 , meaning that if the implementation of KARS standard system increases by 1 unit, then employee competence will also increase by 0.128 units. The Influence of the Implementation of the KARSstandard system on employee competence is significant, with a significant probability value of 0.045 or less than 0.05 . This value is equivalent to the calculated C.R value of 2.002 , or greater than 1.96 so that the $\mathrm{Ha}_{1}$ hypothesis can be accepted, and $\mathrm{Ho}_{2}$ is rejected.

This condition is due to the application of quality standards, including the KARS standard system which has changed the cultural orientation of RSUZA towards a higher quality culture that is a culture that complies with regulations, prioritizes on satisfying public services, and have a good work ethic so that organizational performance will be better (Hardjosoedarmo, 2004).The implementation of the Hospital Quality Standard based on KARS will be able to better control the internal operational processes through the provision of recommendations for improvement so that hospitals can find out the services that are below standard or need to be improved. By knowing comparisons based on accreditation standards, hospitals can use them for the sake of budget submission and hospital planning/ development (Triwibowo, 2012).

\section{H3 (Accepted) :The effect of employee competence on performance}

Employee competence has a positive influence on improving the performance of RSUZA with an influence value of 0.463 , meaning that if the competency of employees at the hospital can increase by 1 unit, then the performance of the hospital will increase by 0.463 . The influence of employee competence in the performance of the RSUZA is significant, with a significant probability value of 0.00 or less than 0.05 . This value is equivalent to the calculated C.R value of 6.672, or greater than 1.96 so that the $\mathrm{Ha}_{3}$ hypothesis can be accepted and $\mathrm{Ho}_{3}$ is rejected. This condition is caused because with good competence, leaders and employees will have theright level of concern in working or trying to work better above the standard. Competence also reduces uncertainty at work and seeks to act more than what is needed or expected in the work system (initiative) (Spencer \& Spencer, 1993) in (Sule \& Priansa, 2018).

\section{H4 (Accepted) :The Influence of KARS standard systemon the performance of the hospital through competence}

The testing of the effect of mediating competence by implementing KARS on hospital performance can be explained as follows: 


\section{International Journal of Business Management and Economic Review}

Vol. 3, No. 01; 2020

ISSN: 2581-4664

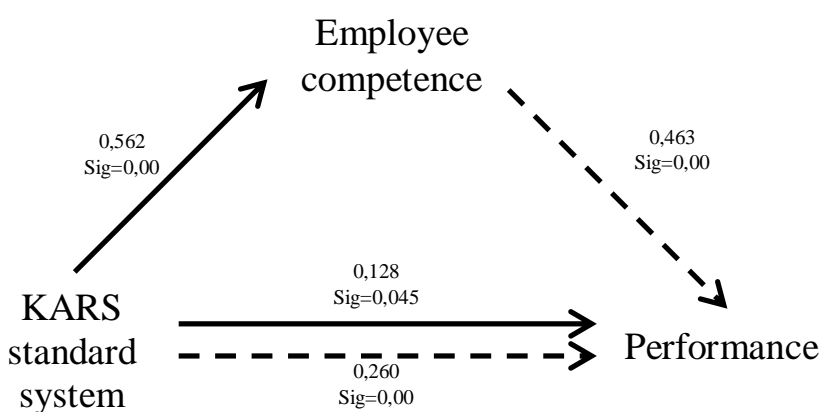

Figure 4. Mediation Effect Testing

The figure 4 above explains that the implementation of the KARS standard system directly influences the increase in employee competency with an estimated value of 0.562 . Then, employee competence directly influences in improving hospital performance with an estimated value of 0.463 . The implementation of KARS standard systemalso directly improves the hospital performance with an estimated value of 0.128. However, the estimated value of the implementation of KARS standard systemon hospital performance is relatively smaller than the effect of the competence variable on hospital performance.

Indirectly, the implementation of the KARS standard systemon hospital performance through employee competencies has an estimated value of 0.260 . This result means that competence has served as a mediating variable in increasing the effect of KARS standard system on the performance on hospital performance.

The amount of the indirect coefficient obtained from the multiplication of the coefficient of the variable of KARS standard systemon employee competency and hospital performance is positive, with a value of 0.260 . While the standard error value of the multiplication of the three variables can be done as follows:

$\mathrm{S} 12=\sqrt{\mathrm{P}^{2} \cdot \mathrm{Se}^{2}+\mathrm{P}^{2} \cdot \mathrm{Se}^{2}+\mathrm{Se}^{2} \cdot \mathrm{Se}^{2}} \sqrt{\mathrm{P}^{2} \cdot \mathrm{Se}^{2}+\mathrm{P}^{2} \cdot \mathrm{Se}^{2}+\mathrm{Se}^{2} \cdot \mathrm{Se}^{2}}$

$\mathrm{S} 12=\sqrt{(0,562)^{2} \cdot(0,0789)^{2}+(0,463)^{2} \cdot(0,056)^{2}+(0,056)^{2} \cdot(0,0789)^{2}}$

$\mathrm{S} 12=\sqrt{(0,316) \cdot(0,0062)+(0,214) \cdot(0,00313)+(0,00313) \cdot(0,00623)}$

$S 12=\sqrt{(0,00196) \cdot(0,0006)+(0,000019)} \sqrt{(0,00196) \cdot(0,0006)+(0,000019)}$

$S 12=\sqrt{0,0000266} \sqrt{0,0000266}$

$\mathrm{S} 12=0,00516$ 
Vol. 3, No. 01; 2020

ISSN: 2581-4664

$\mathrm{CR}=\frac{\mathrm{P} 12}{\mathrm{~S} 12}=\frac{0,260}{0,00516}=50,43 \frac{\mathrm{P} 12}{\mathrm{~S} 12}=\frac{0,260}{0,00516}=50,43$

$\operatorname{Sig}=0,00$

Based on the estimation results, it can be explained that the application of the 2012 KARS Version of the Hospital Quality Standard System influences the hospital performance through competence with an estimated value of 0.260 . This result means that the role of competence in improving the relationship between the application of the 2012 KARS Version of the Hospital Quality Standard System to hospital performance is 0.260 . The influence is significant with a significant probability value of 0.00 or less than 0.05 . This value is equivalent to the calculated C.R value of 5.043, or greater than 1.96 so that the $\mathrm{Ha}_{4}$ hypothesis can be accepted and $\mathrm{Ho}_{4}$ is rejected.

This condition is due to the implementation of the 2012 KARS Version of the Hospital Quality Standard System, which has caused substantial changes. With the implementation of a KARS, all resources at the RSUZA will be evaluated and improved, especially in the human resource field. All employees will be given the training and education according to standards so that organizational failure and obstacles can be anticipated (Hardjosoedarmo, 2004).

\section{CONCLUSION}

The result shows that KAR Standard system has a significant effect on employee competence, the KARS standard system has a significant effect on the performance, employee competence has a significant effect on performance, and employee competence has a mediation role in increasing the effect of KARS standard system on the performance of RSUZA. These results contribute to the update the causality theories especially in management field, and also can be a reference for the practical persons especially the managers in RSUZA in developing their strategy. The limitation resides in the amount of variables that are only three, and also with the one object only. The originality lies in the model that combines several models from the previous ones, and uses SEM as the analysis method. Based on the model, some actionsmay take to increase the performance of RSUZA, like training and developing the employee skills to fulfill the KARS standards.

\section{REFERENCES}

Cahyawati, A. N., Pratikto, \& Soenoko, R. (2013). Nalisis Pengukuran Kinerja Rumah Sakit Dengan Menggunakan Metode Performance Prism. Journal of Engineering and Management in Industrial System, 1(1), 1-7. https://doi.org/10.1016/B0-12-3693985/00467-9

Crosby, F. (1984). The denial of personal discrimination. American Behavioral Scientist, 27(3), 371-386. https://doi.org/https://doi.org/10.1177/000276484027003008

Hardjosoedarmo, S. (2004). Total Quality Management. Yogyakarta: Andi.

Kars. (2011). Standar Akreditasi Rumah Sakit. Jakarta: Kementerian Kesehatan Republik Indonesia.

Kaziliūnas, A., \& Vyšniauskienè, L. (2014). Impact of different quality management system implementation patterns on performance outcomes. Intelektine Ekonomika, 8, 140-155. 


\section{International Journal of Business Management and Economic Review}

Vol. 3, No. 01; 2020

ISSN: 2581-4664

https://doi.org/http://dx.doi.org/10.13165/IE-14-8-1-10

Ng, G. K. B., Leung, G. K. K., Johnston, J. M., \& Cowling, B. J. (2013). Factors affecting implementation of accreditation programmes and the impact of the accreditation process on quality improvement in hospitals: A SWOT analysis. Hong Kong Medical Journal, 19(5), 434-446. https://doi.org/10.12809/hkmj134063

Pasolong, H. (2008). Teori Administrasi Publik, Alfabeta. Bandung.

Spencer, L. M., \& Spencer, S. M. (1993). Competence at Work, Models For Superior Performance. Canada: John Wiley \& Sons, Inc.

Sule, E. T., \& Priansa, D. J. (2018). Kepemimpinan dan perilaku organisasi : (membangun organisasi unggul di era perubahan (Anna, Ed.). Bandung: Refika Aditama.

Torang, S. (2013). Organisasi dan Manajemen: Perilaku, Struktur, Budaya \& Perubahan Organisasi. Bandung: Alfabeta.

Triwibowo, C. (2012). Perizinan dan Akreditasi Rumah Sakit Sebuah Kajian Hukum Kesehatan. Yogyakarta: Nuha Medika.

Utami, T. N., \& Basista, R. (2011). Pengaruh Penerapan Sistem Manajemen Mutu Iso 9001:2008 Tentang Pelaksanaan Ujian Akhir Semester Terhadap Kompetensi Karyawan Pengujian Di Unit Program Belajar Jarak Jauh - Universitas Terbuka Pekanbaru. Jurnal Organisasi Dan Manajemen, 7(2), 157-167.

Wibowo. (2016). Manajemen Kinerja (kelima). Jakarta: PT. Rajagrafindo Persada.

Zaim, H., Yaşar, M. F., \& Ünal, Ö. F. (2013). Analyzing The Effects Of Individual Competencies On Performance: A Field Study In Services Industries In Turkey. Journal of Global Strategic Management, 7(2), 67-77. https://doi.org/DOI: 10.20460/JGSM.2013715668 